Indian J. Anim. Hlth. (2020), 59(1) : 62-66

DOI: $10.36062 /$ ijah.59.1.2020.62-66

Research Article

\title{
EFFECTS OF REPLACING CONVENTIONAL DIETS WITH BREWER'S RICE BYPRODUCTS ON PERFORMANCE OF CROSSBRED (HAMPSHIRE X GHUNGROO) GROWER PIGS
}

\author{
K. BARMAN ${ }^{1 *}$, S. BANIK ${ }^{1}$, R. THOMAS ${ }^{1}$, GOKULDAS PP ${ }^{1}$, P. KAUSHIK ${ }^{2}$, S. KUMAR $^{1}$, \\ B. C. DAS ${ }^{1}$, A. K. DAS ${ }^{1}$, D. KONWAR ${ }^{3}$ AND S. RAJKHOWA ${ }^{1}$
}

${ }^{1}$ ICAR-National Research Centre on Pig, ICAR, Rani-781 131, Guwahati, Assam, India ${ }^{2}$ CVSc, Assam Agricultural University, Khanapara- 781 022, Guwahati, Assam, India ${ }^{3}$ FVSc \& AH, SKUAST-Jammu, Jammu-181 102, Jammu \& Kashmir, India

\begin{abstract}
Twenty four crossbred (HS x GH) grower pigs (about 2 months old, body wt. ranged from $12.34 \pm 0.51$ to $13.53 \pm 1.53 \mathrm{~kg}$ ) of either sex were divided into four groups using randomized block design. Four different diets were used for feeding of the animals namely - $T_{1}$ : standard grower ration without brewer's rice byproducts $(B R B)$; $T_{2}$ : standard grower ration substituted with $25 \% \mathrm{BRB} ; \mathrm{T}_{3}$ : standard grower ration substituted with $50 \% \mathrm{BRB} ; \mathrm{T}_{4}: 100 \%$ BRB. The crude protein content $(\% \mathrm{DM})$ of the ration was $17.71 \pm 0.07$ while that of $B R B$ was $19.59 \pm 0.59$. The average dry matter intake were $(\mathrm{kg} / \mathrm{d}) 1.33 \pm 0.05,1.19 \pm 0.16,1.14 \pm 0.12$ and $0.90 \pm 0.03$, respectively which was reduced significantly $(P<0.01)$ in $T_{3}$ and $T_{4}$ groups in comparison to $T_{1}$ and $T_{2}$ groups. Digestibility coefficients $(\%)$ of dry matter, organic matter, crude protein and nitrogen free extracts were increased $(P<0.05)$, while digestibility coefficients of crude fiber were reduced $(P<0.05)$ significantly with increased level of brewer's byproduct in the ration while no differences in ether extract digestibility. The growth (g/ d) was similar in $T_{1}, T_{2}$ and $T_{3}$ groups while reduced $(P<0.01)$ in $T_{4}$. The feed conversion ratio (FCR) was found similar in $T_{1} T_{2}$ and $T_{3}$ groups while reduced $(P<0.01)$ in $T_{4}$ group. The cost $\left(R s / k g\right.$ gain) was found similar in $T_{1}, T_{2}$ and $T_{3}$ groups while reduced $(P<0.01)$ in $T_{4}$ group. From this study, it is concluded that $50 \%$ replacement of whole concentrate with $B R B$ can meet the nutritional requirement of grower crossbred pigs without affecting growth and FCR.
\end{abstract}

Key words: Brewer's rice byproduct, Concentrate, Crossbred, Grower, Pigs

In pig production, feed alone represent $70-75 \%$ of total cost of production. In intensive pig production, pig directly compete with human being for feeding, since conventional fattening is based on the feeding of cereals like maize, wheat, oats, barley etc along with other protein, mineral and vitamin supplement. Farmers are unable to support costly feeding program because of high cost of cereals and oil cakes. As a result, animal nutritionist used to search for new feed resources especially unconventional feeds in order to produce economic feeding programme for pig and other livestock (Abd El-Hack et al., 2017a; 2017b). Brewer's rice byproduct is one of such unconventional feed resource used by farmers to reduce the feed cost for swine as well as for other livestock such as Rabbit (Adeniji and Adewole, 2015), lamb (Radzik et al., 2018), broiler chicken (Abd El-Hack et al., 2019) and beef cattle (Stefanello et al., 2019).

Brewer's grains are quite rich in protein (27$33 \% \mathrm{DM}$ ), which makes them a valuable source of protein. Brewer's grains are usually fed dried

\section{"Corresponding Author}


to pigs, as they are easier to store and more stable (Blair, 2007). In temperate countries, dried brewer's grains are often not recommended for starter pigs and should only be given in limited amounts to growing or finishing pigs as well to lactating sows (Holden and Zimmerman, 1991). It is reported that brewer's grain can be included as high as 20 to $45 \%$ (diet DM) in growing pigs (Amaefule et al., 2009; Albuquerque et al., 2012) or even higher up to $60 \%$ as reported by Ugye et al. (1988). It can be included up to $40 \%$ in sows ration without any detrimental effect on reproduction as reported by Wahlstrom and Libal (1976). However, higher rates tend to be detrimental to intake and performance (Young and Ingram, 1968). Brewer's grain can be part of basal diets in combination with palm kernel meal and cassava meal (Amaefule et al., 2009). Several workers (Yaakugh et al., 1994) had reported that dried brewer's grains can totally replace rice bran; partially replace maize grain (up to $45 \%$ ), copra meal $(50 \%)$ and concentrates (8-9\%), and it is cost effective (Yaakugh et al., 1994; Amaefule et al., 2006). Brewer's rice product is locally known as 'Mewa' or 'Juguli' and it is abundantly available in the tribal areas of North Eastern State of India. In the present studies, brewer's rice byproduct was used at different levels by replacing whole concentrate to see its effect on growth and nutrient utilization in crossbred grower pigs.

\section{MATERIALS AND METHODS}

The experiment was conducted after approval from the institute animal ethics committee. Twenty four crossbred (HS x GH) grower pigs (about 2 months old, body wt. ranged from $12.34 \pm 0.51$ to $13.53 \pm 1.53 \mathrm{~kg}$ ) of either sex were divided into four groups of six each in a randomized block design. Four different diets were used for feeding of the animals namely - $\mathrm{T}_{1}$ : standard grower ration without brewer's rice byproducts (BRB), control diet, $\mathrm{T}_{2}$ : standard grower ration substituted with $25 \% \mathrm{BRB}, \mathrm{T}_{3}$ : standard grower ration substituted with $50 \% \mathrm{BRB} \mathrm{T}_{4}: 100 \% \mathrm{BRB}$ mixed with required salt and mineral mixtures similar to standard diet. The nutrient requirement of pigs was made as per BIS (1986). The pigs were fed on the experimental grower rations twice daily in the morning and evening. The experiment was conducted for a period of one month. Digestibility trial was conducted at the end of the experiment. The lysine and methionine are balanced in all the rations as per requirement. The calculated energy (ME, Kcal/kg) of experimental diet was 3000 , 3152, 3304 and 3600, respectively in $\mathrm{T}_{1}, \mathrm{~T}_{2}, \mathrm{~T}_{3}$ and $\mathrm{T}_{4}$. The protein content of the experimental diet was $17.71 \pm 0.21,18.18 \pm 0.39,18.94 \pm 0.06$ and $19.59 \pm 0.59$, respectively in $T_{1}, T_{2}, T_{3}$ and $T_{4}$. Proximate composition was done as per AOAC (1990).

Statistical analysis: Feed intake, nutrient digestibility, nitrogen balance, feed conversion ratio (feed gain ratio), feed cost per $\mathrm{kg}$ gain, average daily weight gain was subjected to a oneway ANOVA with experimental diet $\left(\mathrm{T}_{1}, \mathrm{~T}_{2}, \mathrm{~T}_{3}\right.$ and $\mathrm{T}_{4}$ ) as fixed effect as per Snedecor and Cochran (1989). Differences were considered significant when $\mathrm{P}<0.05$ and $\mathrm{P}<0.01$.

\section{RESULTS}

The protein content (\% DM) of the ration was $17.71 \pm 0.21$ and that of brewer's rice byproducts (BRB) was 19.59 \pm 0.59 . Nitrogen free extract content (\% DM) of the ration was $68.10 \pm 0.82$ and that of BRB was 73.86 \pm 0.93 (Table 1).

The digestibility coefficient of DM ranged from $84.88 \pm 1.66$ to $93.46 \pm 0.25$ in $\mathrm{T} 1$ to $\mathrm{T} 4$ respectively. Similarly, CP digestibility was ranged from $74.59 \pm 0.51$ to $78.74 \pm 0.07$ in $\mathrm{T} 1$ to $\mathrm{T} 4$ respectively. The digestibility of OM and NFE also followed the same patterns, while digestibility of crude fiber decreased and digestibility of EE did not follow any pattern (Table 2).

The dry matter intake $(\mathrm{kg} / \mathrm{d})$ ranged from $1.33 \pm 0.05$ in $\mathrm{T}_{1}$ to $0.90 \pm 0.03$ in $\mathrm{T}_{4}$ group. The average gain in weight $(\mathrm{g} / \mathrm{d})$ was ranged from $498.81 \pm 31.7305$ in $T_{1}$ to $157.14 \pm 5.07$ in $T_{4}$ group. The FCR was ranged from $3.07 \pm 0.22$ in $\mathrm{T}_{1}$ to $5.76 \pm 0.20$ in $\mathrm{T}_{4}$ group (Table 3). 
Table 1. Proximate composition (on \% DM) of experimental ration and brewer's rice product

\begin{tabular}{lcccccc}
\hline \multicolumn{1}{c}{ Diet } & OM & CP & CF & EE & Ash & NFE \\
\hline Brewer's rice products & $97.12 \pm 0.75$ & $19.59 \pm 0.59$ & $1.71 \pm 0.23$ & $1.97 \pm 0.18$ & $2.88 \pm 0.75$ & $73.86 \pm 0.93$ \\
Grower ration & $94.44 \pm 0.07$ & $17.71 \pm 0.21$ & $5.03 \pm 0.40$ & $3.60 \pm 0.57$ & $5.57 \pm 0.07$ & $68.10 \pm 0.82$ \\
\hline
\end{tabular}

Table 2. Effect of brewer's rice product on digestibility coefficient of various nutrients in crossbred (HSxGH) grower pigs

\begin{tabular}{lcccccc}
\hline Groups & DM & OM & CP & EE & CF & NFE \\
\hline $\mathrm{T}_{1}$ & $84.88^{\mathrm{a}} \pm 1.66$ & $87.45^{\mathrm{a}} \pm 1.26$ & $74.59^{\mathrm{a}} \pm 0.51$ & $88.20 \pm 0.34$ & $68.05^{\mathrm{a}} \pm 2.30$ & $88.43^{\mathrm{a}} \pm 1.42$ \\
$\mathrm{~T}_{2}$ & $85.70^{\mathrm{a}} \pm 2.45$ & $88.63^{\mathrm{a}} \pm 1.92$ & $75.85^{\mathrm{b}} \pm 1.09$ & $87.59 \pm 1.19$ & $66.02^{\mathrm{a}} \pm 0.19$ & $93.43^{\mathrm{b}} \pm 1.35$ \\
$\mathrm{~T}_{3}$ & $89.10^{\mathrm{b}} \pm 0.13$ & $91.18^{\mathrm{b}} \pm 0.01$ & $76.89^{\mathrm{b}} \pm 0.34$ & $85.56 \pm 2.90$ & $64.51^{\mathrm{b}} \pm 0.86$ & $95.86^{\mathrm{c}} \pm 0.16$ \\
$\mathrm{~T}_{4}$ & $93.46^{\mathrm{c}} \pm 0.25$ & $94.83^{\mathrm{c}} \pm 0.18$ & $78.74^{\mathrm{c}} \pm 0.07$ & $89.69 \pm 1.67$ & $58.20^{\mathrm{c}} \pm 1.61$ & $94.75^{\mathrm{d}} \pm 0.14$ \\
$\mathrm{P}$ Value & 0.131 & 0.106 & 0.110 & 0.705 & 0.100 & 0.06 \\
\hline Level of & $*$ & $*$ & $*$ & NS & $*$ & $*$
\end{tabular}

significance

a, b, c, d different superscript in a column differ significantly $(*, P<0.05), \mathrm{T}_{1}: 0 \%$ replacement of concentrate with brewer's rice byproducts; $\mathrm{T}_{2}: 25 \%$ replacement of concentrate with brewer's rice byproducts; $\mathrm{T}_{3}: 50 \%$ replacement of concentrate with brewer's rice byproducts; $\mathrm{T}_{4}: 100 \%$ replacement of concentrate with brewer's rice byproducts

Table 3. Effect of brewer's rice products on nutrient utilization in crossbred grower pigs

\begin{tabular}{lcccccc}
\hline Parameters & $\mathbf{T}_{\mathbf{1}}$ & $\mathbf{T}_{\mathbf{2}}$ & $\mathbf{T}_{\mathbf{3}}$ & $\mathbf{T}_{\mathbf{4}}$ & $\begin{array}{c}\mathbf{P} \\
\text { value }\end{array}$ & $\begin{array}{c}\text { Level of } \\
\text { significance }\end{array}$ \\
\hline DMI, g/day & $1.33^{\mathrm{a}} \pm 0.05$ & $1.19^{\mathrm{ab}} \pm 0.16$ & $1.12^{\mathrm{b}} \pm 0.11$ & $0.90^{\mathrm{c}} \pm 0.03$ & 0.01 & $* *$ \\
Initial b wt & $13.53 \pm 1.53$ & $12.34 \pm 0.51$ & $12.44 \pm 1.37$ & $12.93 \pm 1.54$ & 0.879 & $\mathrm{NS}$ \\
Final b wt & $24.00^{\mathrm{a}} \pm 2.11$ & $19.48^{\mathrm{a}} \pm 1.10$ & $19.73^{\mathrm{a}} \pm 1.54$ & $14.83^{\mathrm{b}} \pm 1.80$ & 0.032 & $*$ \\
Average gain, g & $498.81^{\mathrm{a}} \pm 31.73405 .71^{\mathrm{a}} \pm 33.99$ & $415.48^{\mathrm{a}} \pm 9.73$ & $157.14^{\mathrm{b}} \pm 5.07$ & 0.01 & $* *$ \\
Feed conversion ratio3.07 \pm 0.22 & $3.23^{\mathrm{a}} \pm 0.23$ & $4.24^{\mathrm{a}} \pm 0.29$ & $5.76^{\mathrm{b}} \pm 0.20$ & 0.01 & $* *$ \\
Feed cost/kg gain & $68.57^{\mathrm{a}} \pm 4.92$ & $67.97^{\mathrm{a}} \pm 6.41$ & $67.98^{\mathrm{a}} \pm 6.82$ & $40.38^{\mathrm{b}} \pm 1.69$ & 0.003 & $* *$ \\
\hline
\end{tabular}

a,b,c different superscript in a row differ significantly $(* *, \mathrm{P}<0.01 *, \mathrm{P}<0.05), \mathrm{T}_{1}: 0 \%$ replacement of concentrate with brewer's rice byproducts; $\mathrm{T}_{2}: 25 \%$ replacement of concentrate with brewer's rice byproducts; $\mathrm{T}_{3}: 50 \%$ replacement of concentrate with brewer's rice byproducts; $\mathrm{T}_{4}: 100 \%$ replacement of concentrate with brewer's rice byproducts

\section{DISCUSSION}

The digestibility coefficient of dry matter, organic matter and crude protein was increased $(\mathrm{P}<0.05)$ with increased level of $\mathrm{BRB}$ in the ration while digestibility coefficient of crude fiber and nitrogen free extract was increased with increased level of BRB up to a level of 50 percent and thereafter their digestibility was reduced $(\mathrm{P}<0.05)$ significantly (Table 2). In contrast to the present findings, Amaefule et al. (2006) found higher digestibility of ether extract and crude fiber at
$35 \%$ inclusion of brewer's dried grains (BDG) than $30 \%$ level of BDG higher level of feeding of brewer's dried grains, which might be due to diet composition (Myer et al., 1975), animal variation (Zivkovic and Bowland, 1970) etc.

Average DM intake (g/d) was decreased with increased level of brewer's rice products. Decreased in feed intake upon supplementation of wet brewer's grains was also reported by 
other workers (Lazarevich and Lesnov, 2010). Average growth rate (g/day) was found similar in $\mathrm{T}_{1} \mathrm{~T}_{2}$ and $\mathrm{T}_{3}$ groups while reduced significantly at $50 \%$ replacement of concentrate with BRB in grower crossbred pig and decreased $(\mathrm{P}<0.01)$ at $100 \%$ replacement of concentrate with BRB (Table 3). Growth was found similar in group $\mathrm{T}_{1}$, $\mathrm{T}_{2}$ and $\mathrm{T}_{3}$ while decreased significantly $(\mathrm{P}<0.01)$ at $100 \%$ replacement of concentrate with BRB. In contrast to present finding, it was reported that inclusion of dried brewer's grain up to $25 \%$ in poultry diet without addition of enzyme decreased the weight gain (Alabi et al., 201 4).

In similar manners, feed conversion ratio was not differed in $T_{1}, T_{2}$ and $T_{3}$ groups while reduced $(\mathrm{P}<0.01)$ at $\mathrm{T}_{4}$ group. The feed cost per $\mathrm{kg}$ gain was found similar in $\mathrm{T}_{1}, \mathrm{~T}_{2}$ and $\mathrm{T}_{3}$ groups while reduced $(\mathrm{P}<0.01)$ significantly in $\mathrm{T}_{4}$ group (Table 3). The increase digestibility of DM, OM, $\mathrm{CP}$ and NFE with increased level of BRB in the ration might be due to low crude fiber level in BRB. Ashour et al. (2019) also found better feed conversion efficiency in broilers fed on diet containing 9\% dried brewer's grain. Similarly, Ironkwe and Bamgbose (2011) also reported better growth and feed conversion efficiency by utilizing dried brewer's grain at $0 \%, 25 \%, 50 \%$, $75 \%$ and $100 \%$ by replacing maize in broiler finishers bird.

It is reported that dried brewer's grains can totally replace rice bran, partially replace maize grain (up to $45 \%$ ), copra meal (50\%), and concentrates (8-9\%) as reported by several workers (Yaakugh et al., 1994). Inclusion rates tend to be higher in

\section{REFERENCES}

Abd El-Hack ME, Alagawany M, El-Sayed SAA and Fowler J, 2017a. Influence of dietary inclusion of untreated or heat-treated Jatropha meal on productive and reproductive performances and biochemical blood parameters of laying Japanese quail. Poult Sci, 96: 2761-2767

Abd El-Hack ME, El-Hindawy MM, Attia AI and Mahrose KM, 2017b. Does the use of distiller's dried grains with solubles (DDGS) in layer diets temperate countries, ranging from 20 to $45 \%$ (diet DM) in growing pigs (Amaefule et al., 2009; Albuquerque et al., 2012). Inclusion rates as high as 60\% have been used (Ugye et al., 1988). It is reported that in tropical and subtropical climates, rates of $30 \%$ in weaner pigs and $40-50 \%$ in finishing pigs have been proposed and have been found cost-effective in spite of the performance losses (Meffeja et al., 2007).

It is reported that wet or ensiled brewer's grains can be used in pig diets, but they tend to have a depressive effect on feed intake, DM and energy digestibility, animal performance and carcass dressing (Lazarevich and Lesnov, 2010). In temperate countries, they are only recommended for finishing pigs (over $60 \mathrm{~kg}$ ) and lactating sows, at about $20 \%$ inclusion rate or $1-2 \mathrm{~kg} / \mathrm{d}$ (up to 3 $\mathrm{kg}$ ) (Blair, 2007). In tropical and subtropical climates, rates of $30 \%$ in weaner pigs and 40 $50 \%$ in finishing pigs have been proposed and have been found cost-effective in spite of the performance losses (Meffeja et al., 2007). Amoah et al. (2017) reported a significant reduction of feed cost at 17 and $20 \%$ level of inclusion of sun dried brewer's spent grain in pigs. Similarly, in the present study cost per $\mathrm{kg}$ gain was reduced non significantly in $\mathrm{T}_{2}$ and $\mathrm{T}_{3}$ groups and significantly at $\mathrm{T}_{4}$ group in comparison to $\mathrm{T}_{1}$ group.

From the present study, it is concluded that, 50\% replacement of whole concentrate with brewer's rice product can meet the nutritional requirement of grower crossbred pigs without affecting the growth and feed conversion efficiency.

affect the nutrients digestibility and manure pollution by nitrogen and phosphorous?. Environ Sci Poll Res, 24: 13335-13343

Abd El-Hack ME, Alagawany M, Patra A, Latif MA, Ashour EA et al., 2019. Use of brewers dried grains as an unconventional feed ingredient in the diets of broiler chickens: A review. Adv Anim Vet Sci, 7(3): 218-224

Adeniji AA and Adewole OA, 2015. Effects of feeding 
graded levels of brewers dried grains with or without probiotics supplementation in replacing groundnut cake in the diet of weaned rabbits. J Natural Sci Res, 5(7): 155-163

Alabi OO, Atteh JO, Adejumo IO and Ogundele OO, 2014. Effects of dietary levels of brewers' dried grain supplemented with commercial enzymes on performance, nutrient retention and gastrointestinal tract characteristics of Arbor Acres broilers. Int J Agri Innov Res, 2: 2319-1473

Albuquerque DM de N, Lopes JB, Segundo LF de F, Brandão TM, Ribeiro MN et al., 2012. Dehydrated brewery residue for pigs in the growth phase under high temperature conditions. Rev Bras Zoot, 41: 1784-1788

Amaefule KU, Onwudike OC, Ibe SN and Abasiekong SF, 2009. Nutrient utilization and digestibility of growing pigs fed diets of different proportions of palm kernel meal and brewer's dried grain. Pakistan J Nutr, 8: 361-367

Amaefule KU, Onwudike OC, Ibe SN and Abasiekong SF, 2006. Performance, cost benefit, carcass quality and organ characteristics of pigs fed high graded levels of brewer's dried grain diets in the humid tropics. Pakistan J Nutr, 5: 242-247

Amoah KO, Asiedu P, Wallace P, Bumbie GZ and Rhule SWA, 2017. The performance of pigs at different phases of growth on sun-dried brewer's spent grain. Livest Res Rur Dev, 29(5), Article \#90, from http://www.lrrd.org/lrrd29/5/kwam29090.html

AOAC, 1990. Official Methods of Analalysis, $15^{\text {th }}$ edn. (Eds. Kenneth Helrich), Association of Official Analytical Chemists, Inc., Suite 400, 2200 Wilson Boulevard, Arlington, Virginia 22201, USA

Ashour EA, Abd El-Hack ME, El-Hindawy MM, Attia AI , Osman, AO et al., 2019. Impacts of dietary inclusion of dried brewers' grains on growth, carcass traits, meat quality, nutrient digestibility and blood biochemical indices of broilers. South African J Anim Sci, 49 (3), doi: 10.4314/sajas.v49i3.18

BIS, 1986. BIS Specifications for Compounded Feeds for Pigs (IS: 7472 - 1986), Bureau of Indian Standard, 1986, India

Blair R, 2007. Nutrition and feeding of organic pigs. Cabi Series, CABI, Wallingford, UK

Holden PJ and Zimmerman DR, 1991. Utilization of cereal grain by-products in finishing swine. In:
Miller, E.R., Ullrey, D.E. and Lewis, A.J. (eds) Swine Nutrition. Butterworth-Heinemann, Burlington, Massachusetts, pp585-593

Ironkwe MO and Bamgbose AM, 2011 Effect of replacing maize with brewer's dried grain in broiler finisher diet. Int J Poult Sci, 10: 710-712

Lazarevich AN and Lesnov AP, 2010. Brewer's spent grain in pig feeding. Svinovodstvo, 8: 46-48

Meffeja F, Njifutie N, Manjeli, Tchoumboue YJ and Tchakounte J, 2007. Comparative digestibility of diets containing ensiled brewer's grains, palm kernel cake or cocoa pod husk in growing finishing pigs in Cameroon. Livest Res Rur Dev, 19: 70

Myer RO, Cheeke PR and Kennick WH, 1975. Utilization of alfalfa protein concentrates by swine. J Anim Sci, 40: 885-891

Radzik R, Aurelia R, Niżnikowski W, Świątek R, Szymañska M et al., 2018. The effect of the addition of wet brewers grain to the diet of lambs on body weight gain, slaughter value and meat quality. Arch Anim Breed, 61: 245-251

Snedecor GW and Cochran WG, 1989. Statistical Methods, $8^{\text {th }}$ edn., Iowa University press, Ames, Iowa (USA)

Stefanello FS, Fruet APB, Trombetta F, da Fonseca PAF, Dos Santos da Silva Met al., 2019. Stability of vacuum-packed meat from finishing steers fed different inclusion levels of brewer's spent grain. Meat Sci, 147: 155-161

Ugye BH, Anugwa FOI and Nwosu CC, 1988. Effects of varying levels of dietary dried brewer's grains on performance and carcass characteristics of growing pigs. Bull Anim Health Prod Afr, 36: 31-37

Wahlstrom RC and Libal GW, 1976. Brewer's dried grains as a nutrient source in diets for pregnant sows. J Anim Sci, 42: 871-875

Yaakugh I, Tegbe TSB, Olorunj SAS and Aduku AO, 1994. Replacement value of brewer's dried grain for maize on performance of pigs. J Sci Food Agric, 66: 465-471

Young LG and Ingram RH, 1968. Dried brewer's grains in rations for market hogs. Can J Anim Sci, 48: 83-88

Zivkovic S and Bowland JP, 1970. Influence of substituting higher fibre ingredients for corn on the digestibility of diets and performance of sows and litters. Can J Anim Sci, 50: 177-184 